Canadian

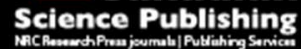

Canadian Journal of Microbiology Revue canadienne de de microbiologie

\title{
Estimating genetic structure and diversity of cyanobacterial communities in Atlantic forest phyllosphere
}

\begin{tabular}{|r|l|}
\hline Journal: & Canadian Journal of Microbiology \\
\hline Manuscript ID & cjm-2016-0229.R1 \\
\hline Manuscript Type: & Article \\
\hline Date Submitted by the Author: & 07-Jun-2016 \\
\hline Complete List of Authors: & $\begin{array}{l}\text { Rigonato, Janaina; CENA-USP, DVPROD } \\
\text { Gonçalves, Natalia; University of Sao Paulo } \\
\text { Andreote, Ana; University of São Paulo, Center for Nuclear Energy in } \\
\text { Agriculture } \\
\text { Lambais, Marcio; ESALQ } \\
\text { Fiore, Marli; CENA-USP, }\end{array}$ \\
\hline Keyword: & Tropical forest, Clone library, DGGE, qPCR \\
\hline & \\
\hline
\end{tabular}

SCHOLARONE $^{\text {Im }}$

Manuscripts 
Estimating genetic structure and diversity of cyanobacterial communities in Atlantic forest phyllosphere

[Running title: Cyanobacteria in Atlantic forest phyllosphere]

Janaina Rigonato ${ }^{1, *}$, Natalia Gonçalves ${ }^{1 *}$, Ana Paula Dini Andreote ${ }^{1}$, Marcio Rodrigues Lambais $^{2}$, Marli Fátima Fiore ${ }^{1 \#}$

${ }^{1}$ University of São Paulo, Center for Nuclear Energy in Agriculture, CENA/USP, Piracicaba-SP, Brazil

${ }^{2}$ University of São Paulo, Department of Soil Science, ESALQ/USP, Piracicaba-SP, Brazil

* Janaina Rigonato and Natalia Gonçalves share the first authorship

\#Corresponding author: Marli Fátima Fiore, Center for Nuclear Energy in Agriculture, University of São Paulo. Av. Centenário 303, Postal Code 96, CEP 13400-970, Piracicaba, SP, Brazil, Tel.: +55 19 3429-4657, Fax: +55 19 3429-4610, e-mail: fiore@cena.usp.br 


\begin{abstract}
Cyanobacterial communities on the phyllosphere of four plant species inhabiting the endangered Brazilian Atlantic Forest biome was evaluated using cultivation-independent molecular approaches. Total genomic DNA was extracted from cells detached from leaves surface of Euterpe edulis, Guapira opposita, Garcinia gardneriana and Merostachys neesii sampled in two Brazilian Atlantic Forest locations along an elevational gradient, i.e., lowland and montane forest. The DNA fingerprinting method PCR-DGGE revealed that the cyanobacterial phyllosphere community structures were mainly influenced by the plant species, with a low effect of the geographical location of the plant. The $16 S r R N A$ gene sequences obtained by clone libraries showed a predominance of nitrogen-fixing cyanobacteria of the order Nostocales, even though the majority of retrieved OTUs ( $60 \%$ of the sequences) showed similarity only to uncultured cyanobacteria phylotypes. The leaf surfaces of Guapira opposita had the highest richness and diversity of cyanobacteria, whereas the M. neesii (bamboo) had the largest number of copies of cyanobacterial $16 S r R N A$ gene per $\mathrm{cm}^{2}$ of leaf. This study investigated cyanobacteria diversity and its distribution pattern in Atlantic forest phyllosphere. The results indicated that plant species is the main driver of cyanobacteria community assemblage in the phyllosphere, and that these communities are comprised by a high diversity of cyanobacterial taxa to be discovered.
\end{abstract}

Key words: Tropical forest, Clone library, DGGE, qPCR. 


\section{Introduction}

The Atlantic Forest bears high levels of biological diversity and endemism (Ribeiro et al., 2009, Colombo and Joly, 2010, Scarano and Ceotto, 2015). Nonetheless, its original area ( 150 million ha) was reduced to approximately 11 to $16 \%$ due to the agricultural expansion and urbanization (Ribeiro et al. 2011). The largest remaining area of continuous forest is located mainly along the coastal mountains of the São Paulo State (Ribeiro et al. 2011). Associated with forest, there is a rich diversity of epiphytic and endophytic microorganisms with essential functions for maintenance and survival of such ecosystems.

The leaf surface (phyllosphere) is a dynamic and stressful environment, subjected to variations of temperature, humidity and incidence of UV radiation (Lindow and Brandl, 2003). Despite these conditions, microenvironments provided by the leaves can harbor a diverse and underexplored microbial community (Lambais et al. 2006, Baldoto and Olivares 2008, Fürnkranz et al. 2008, Peñuelas and Terradas, 2014). Bacterial structure communities from phyllosphere can be determined by plant species and/or its geographical position (Yadav et al. 2004, Lambais et al. 2006, Finkel et al. 2011, Rigonato et al. 2012, Lambais et al. 2014). In addition, the bacterial distribution on the leaf surfaces can be associated with anatomical characteristics and availability of nutrients (micro-environment) (Leveau and Lindow 2001, Monier and Lindow 2003, Dulla et al. 2005). However, Cyanobacteria phylum may be less dependent of the plant for their nutrition since these organisms are autotrophic and some strains can also fix atmospheric nitrogen.

Studies in the Atlantic Forest have revealed high levels of cyanobacterial diversity. Floristics surveys have shown huge morphological richness of cyanobacteria (Branco et al. 2009, Sant'anna et al. 2013, Gama et al. 2014) and novel species and genera have been described (Fiore te al. 2007, Sant' Anna et al. 2010, Hentschke et al. 2016) in this biome. Nevertheless, the 
genetic diversity of the phylum Cyanobacteria inhabiting the Atlantic Forest is still poorly understood.

Even though several studies have characterized the bacterial community in phyllosphere of plants of tropical forests, reports on cyanobacteria community composition in the phyllosphere are scarce (Fürnkranz et al. 2008, Rigonato et al. 2012, Alvarenga et al., 2016, Venkatachalam et al., 2016). Herein, the community structure of cyanobacteria inhabiting phyllosphere of four plant species from the Brazilian Atlantic Forest biome was accessed using cultivationindependent molecular approaches.

\section{Materials and Methods}

Site description and sampling:

The plant leaves were collected in two locations along an elevational gradient within Atlantic Forest in Serra do Mar State Park (São Paulo State): Lowland Forest Permanent Sample Plot E $\left(\mathrm{PSP}_{\mathrm{E}}-23^{\circ} 20^{\prime} 05^{\prime \prime} \mathrm{S} 44^{\circ} 49^{\prime} 55^{\prime \prime} \mathrm{W}\right)$ at the Picinguaba nucleus, municipality of Ubatuba, and

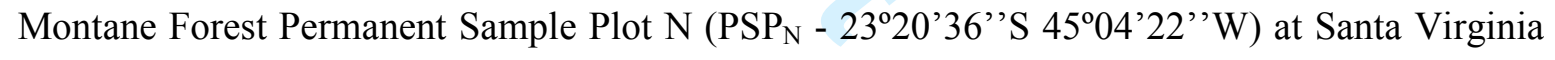
nucleus, municipality of São Luis do Paraitinga. The elevational gradient includes a network of 14 1-ha permanent plots established in 2005-2006 to study forest diversity and dynamics, and ecosystem functioning of the Brazilian Coastal Atlantic Forest (Joly et al. 2012). The lowland forest $\mathrm{PSP}_{\mathrm{E}}$ is inserted in wavy and scarped relief with moderately steep slopes, with altitudes ranging from 64 to $89 \mathrm{~m}$ and an average annual rainfall over 2,200 $\mathrm{mm}$, and an average annual temperature of $22{ }^{\circ} \mathrm{C}$ (Joly et al. 2012). Towards the top of the mountain, there is a gradual cooling along the slope, but there is no reduction in rainfall. The montane forest $\mathrm{PSP}_{\mathrm{N}}$ is almost daily covered by a dense fog, with altitudes ranging from 1010 to $1040 \mathrm{~m}$ and an average annual temperature of $17^{\circ} \mathrm{C}$ (Joly et al. 2012). 
The plant species were selected based on its richness according to a previous study (Joly et al. 2012) in the two different locations. Four adult individuals of Garcinia gardneriana (Planch. \& Triana) Zappi, Guapira opposita (Vell.) Reitz, and Euterpe edulis Mart. in the lowland forest $\mathrm{PSP}_{\mathrm{E}}$ and Merostachys neesii Rupr., G. opposita and E. edulis in the montane forest $\mathrm{PSP}_{\mathrm{N}}$ were sampled randomly, in a total of 24 samples. Approximately 10 leaves of each individual were collected using long reach pruner under canopy (two to eight meters of height). The samples were maintained at $4{ }^{\circ} \mathrm{C}$ until transported to the laboratory, where they were immediately processed to dislodge microbial cells from the leaf surface.

\section{DNA extraction:}

Three intact leaves of 24 samples (four individuals of each plant species and site) were placed in $500 \mathrm{~mL}$ Erleymeyer containing $100 \mathrm{~mL}$ of sterilized $\mathrm{NaCl}$ solution $(9 \% \mathrm{w} / \mathrm{v})$ and glass beads $(3$ $\mathrm{mm} \phi)$ and were subjected to agitation $(230 \mathrm{rpm})$ at $20^{\circ} \mathrm{C}$ for $1 \mathrm{~h}$ to promote detachment of the cells from leaf surfaces. The suspension containing detached cells was transferred to a $50 \mathrm{ml}$ sterile tube and concentrated by centrifugation at $10,000 \mathrm{x}$ g for $20 \mathrm{~min}$. The pellet formed was used to extract total DNA using the kit MoBio Powersoil (Laboratories Inc, Carlsbad, CA, USA) according to manufacturer's instructions. The DNA integrity was confirmed by electrophoresis in agaroses gel $1 \%(\mathrm{w} / \mathrm{v})$ and this DNA was used for the subsequent analysis of PCR-DGGE, qPCR and the clone library construction.

\section{Nested PCR and DGGE:}

The cyanobacterial $16 S$ rRNA gene amplicons of the 24 samples were obtained by Nested PCR using the primer sets 27F1/1494Rc (Neilan et al. 1997) and CYA359F (40 GC bases clamp)/CYA781aR and CYA781bR (equimolar concentration, Nübel et al. 1997). 
DGGE was performed in $6 \%$ polyacrylamide gels with a denaturing gradient $25-60 \%$ of urea and formamide in a constant voltage of $100 \mathrm{~V}$ at $60{ }^{\circ} \mathrm{C}$ for $15 \mathrm{~h}$. DGGE analysis, $300 \mathrm{ng}$ of each amplified sample was used. The gel was stained with silver nitrate (Blum et al. 1987) and photographed using a digital camera. The electrophoretic profiles of DGGE were evaluated using the image analysis system Bionumerics (Applied Maths, NV, Belgium). The presence/absence of each band was identified per sample and a binary matrix was built.

Nonmetric multidimensional scaling was used to investigate the relationships between cyanobacterial community composition and exploratory variables (plant species and sampled sites). The similarity matrix was determined using the Bray-Curtis Index of Similarity (Primer6, Clarke and Gorley 2006). The significance of these patterns was tested by analysis of similarity (ANOSIM), generating a test statistic $\mathrm{R}$, with a score of 1 indicating complete separation and 0 indicating no separation.

\section{Clone libraries:}

Clone libraries of cyanobacterial $16 S r R N A$ gene fragments were obtained for each plant species and sites, in a total of six libraries. Each clone library was constructed using an amplicon pool of four individuals. The amplicons were obtained using the same nested PCR approach described above for PCR-DGGE analysis, except for the absence of the GC clamp in the CYA359F primer. The clone libraries were generated and the sequencing was performed according to described in Rigonato et al. (2012).

Nucleotide sequences were trimmed for the removal of low-quality bases and vector sequences (quality parameter $>20$ ) using the RDP pipeline (http://rdp.cme.msu.edu/index.jsp). The same pipeline was applied to remove chimeric sequences. The sequences are available in GenBank under accession numbers KP769524-KP769531. The sequences were grouped into operational taxonomic units (OTUs) based on an evolutionary distance cut-off of 0.05 using the Mothur 
program (Schloss et al. 2009). OTUs obtained were compared with that available in GenBank by BLAST search and the best hit sequences were selected to represent each clone. Richness (ACE and Chao1) and diversity (Shannon) indices were calculated using Mothur and the clone library estimated coverage (Good 1953) was determined using SPADE program.

The phylogenetic tree was constructed by selecting one representative clone for each OTU and the phylogeny was built using the Kimura two-parameter substitution model distance and Neighbor-Joining method (Saitou and Nei 1987) in the MEGA 5 program (Tamura et al. 2011). Bootstrap analyses involving the construction of 1000 resampled trees were performed.

\section{Real Time PCR (qPCR):}

The cyanobacterial $16 S r R N A$ gene copy number was determined by qPCR. The reactions were conducted in triplicate in reaction: $12.5 \mu \mathrm{l}$ of Platinum SYBR Green qPCR SuperMix-UDG (Life Technologies - Invitrogen, Grand Island, NY, USA), $0.2 \mathrm{mM}$ of each primer CYA359/CYA781A and B (Nübel et al., 1997), $0.5 \mu \mathrm{l}$ of ROX (Life Technologies - Invitrogen) and 10 ng of DNA. The temperature cycling condition was the same used for Nested PCR. The reaction specifity was confirmed by Melting curve analyses. A standard curve was constructed from a serial dilution of target DNA (0.001 to $10 \mathrm{ng}$ of DNA) and the samples CT data were interpolated to determine the copy numbers of target DNA. The results were expressed as log of copies of the $16 S$ rRNA per $\mathrm{cm}^{2}$ leaf. The Student's t-test was used to compare the samples $(\mathrm{P}<0.05)$

\section{Results}

$P C R-D G G E$ :

The DGGE banding profiles showed several equally intense bands, suggesting the presence of a large number of equally abundant ribotypes on all phyllosperes evaluated (data not shown). 
However, the NMDS (stress 0.22) and ANOSIM analysis (Fig. 1A, Table 1, respectively) revealed that the cyanobacterial community structures on the phyllosphere are mainly driven by the plant species. The similarity among cyanobacterial community structures from plants of different locations, in most cases, suggests that the geographical position is a secondary factor shaping the distribution of this group (Fig. 1B, ANOSIM R=0.214, p=0.050). An exception was E. edulis (square in Fig. 1A), which harbored different assemblies of cyanobacteria according to the geographical location.

\section{Clone libraries:}

The cyanobacterial community compositions were evaluated based on 584 sequences. The clone distribution according to plant species and sampling location, phylogenetic assignments, indices of cyanobacterial diversity and richness and estimated sampling coverage are reported in Table 2. The estimated sampling coverage ranged from 74.4 to $89.5 \%$ ( 0.05 cutoff). The cyanobacterial communities on the phyllosphere of the plants from $\mathrm{PSP}_{\mathrm{E}}$ showed higher values of richness, especially G. opposita. However, in $\mathrm{PSP}_{\mathrm{N}}$ M. neesii, had the highest richness index.

The sequences were clustered into 87 OTUs, considering a cutoff of $95 \%$ identity. BLASTn analyses reveled high levels of similarity to several cyanobacterial sequences (Table 2), most of them belonging to heterocytous-filamentous group (Dolichospermum, Brasilonema, Nostoc, Tolypothrix and Scytonema). Furthermore, 60 OTUs upholding nearly $60 \%$ of the total retrieved sequences, matched to uncultivated cyanobacteria sequences in the public database (Table 2). In congruence, the phylogenetic tree (Fig. 2) demonstrated that the OUTs obtained herein, both the previous taxonomically affiliated and some comprising uncultivated sequences, clustered with sequences of known cyanobacteria. However, the majority of the uncultivated OTUs grouped as a separated clade in the phylogram. 


\section{Real time PCR:}

The amplification efficiency factor and $\mathrm{R}^{2}$ obtained were $87 \%$ and 0.99 , respectively, allowing us to confidently estimate the number of cyanobacterial $16 S r R N A$ gene copies per $\mathrm{cm}^{2}$ of leaf of each plant species.

The number of copies of the $16 S r R N A$ gene was significantly higher on the phyllosphere of $M$. neesii (6.12 log of cyanobacterial $16 S r R N A$ gene per $\mathrm{cm}^{2}$ of leaf), than on the phyllosphere of $G$. opposita, G. gardneriana and E. edulis (Fig. 3). Guapira opposita and E. edulis had equal abundances of cyanobacterial $16 S r R N A$ gene copies in both sampled sites, and the three plant species in $\mathrm{PSP}_{\mathrm{E}}$ did not differ statistically.

\section{Discussion}

Cyanobacteria diversity in the Atlantic Forest have been explored mainly using culturedependent approaches (Fiore et al. 2007, Branco et al. 2009, Sant'Anna et al. 2010, 2013, Komárek et al. 2013, Gama et al. 2014, Hentschke et al. 2016). Also, none of the available studies about this biome focused on the phyllosphere micro-habitat. However, there is no information on the cyanobacteria community composition in the phyllosphere of plant species of the Atlantic Forest. The molecular approaches applied in this study assessed the cyanobacteria community inhabiting unexplored phyllospheres of four plant species from Atlantic Forest. This investigation demonstrated that each plant species harbored a particular cyanobacteria community, suggesting that intrinsic factors of each plant species may drive the assemblage of these communities. Previous findings already indicated that different plant species select their own total bacteria community in the Atlantic Forest canopies (Lambais et al. 2006, 2014). A further study suggested that a coevolution may occur between trees and phyllosphere microbial population (Lambais and Crowley 2014). 
Our data also showed that the geographical distance between plants may also affect the structure of cyanobacterial communities. Significant differences in the bacterial community structure in phyllosphere of the same plant species separated by long-distances in the Atlantic forest have been reported (Lambais and Crowley, 2014). Besides the plant genetic component driving the bacterial community structure in the phyllosphere, environmental conditions associated with particular geographical locations can also affect colonization (Finkel et al. 2011). In opposite, a study conducted on mangrove phyllosphere showed that the geographical tree location was the main factor driving cyanobacteria community structure (Rigonato et al. 2012). Likewise, several studies indicate that the age of the leaves, the position in the canopy, anatomical structures, such as trichomes and stomata, light incidence and microclimate can affect the microbial presence in the phyllosphere (Mechaber et al. 1996, Monier and Lindow 2003, Yadav et al. 2004, Lambais et al. 2006, Baldoto and Olivares 2008). Based on the available information, it is likely that the phyllosphere colonization by cyanobacteria is modulated by multiple factors, such as plant species, environmental conditions and geographical location at different scales.

The variation on abundance of cyanobacteria on leaves surfaces for each plant species was also observed. The highest abundance of cyanobacteria was found in the surface leaves of bamboo (M. neesii). This fact may be consequence of the life strategy of this plant species, that differently of the others evaluated, is an r-strategist that colonizes gaps in vegetation, favoring the cyanobacterial growth due to its photoautotrophic metabolism.

Most of the retrieved sequences were affiliated to Nostoc (cutoff 95\%). This genus was also reported as predominant diazotrophic colonizers of phyllospheres in a tropical forest in Costa Rica (Fürnkranz et al. 2008). In general, the high abundance of OTUs affiliated to the diazotrophic order Nostacales suggest that these organisms may contribute to an input of nitrogen to the system. The Brazilian Atlantic Forest soils are highly leached and acidic with very low nutrient availability (Leitão Filho et al. 1993). Despite these constraints, plant 
productivity is remarkable in the forest, indicating that there are alternative sources of nutrients to supply the plant demand. Cyanobacteria were already reported as a significant fraction of the diazotrophic community responsible for $\mathrm{N}_{2}$ fixation in phyllosphere of tropical lowland rainforest (Fürnkranz et al. 2008). Furthermore, $\mathrm{N}_{2}$ fixation in the phyllosphere was suggested as the main mechanism for adding $\mathrm{N}$ in humid tropical ecosystems (Abril et al. 2005). There are evidence that the $\mathrm{N}_{2}$ fixed in the phyllosphere can be incorporated by the plant (Bentley 1987, Fritz-Sheridan and Portécop 1987, Freiberg 1998, Abril et al. 2005, Peñuelas et al., 2012), suggesting an additional mechanism for $\mathrm{N}$ acquisition.

Many of the known cyanobacterial groups detected have occurrence already described in others habitats of the Atlantic Forest, as Chroococcidiopsis (Büdel et al. 2002, Gama et al., 2014), Synechococcus (Branco et al., 2009, Gama et al., 2014), Brasilonema (Fiore at al., 2007) and Scytonema (Komárek et al., 2013). However, the sequence identity was lower than $97 \%$ in many cases. This can be an indicative that a diversity of novel species or species which no genetic information available are represented by these retrieved sequences. Several novel genera and species have been described inhabiting Atlantic Forest different micro-habitats (Fiore et al. 2007, Aguiar et al. 2008, Sant'Anna et al. 2010, Hentschke et al., 2016).

In this study, a great number of $16 S r R N A$ sequences retrieved from the studied phyllospheres matched uncultured cyanobacteria and the low identity of some OTUs to sequences available in the GenBank database point out that a high number of taxa remain to be described in this environment. Similar results were reported for the mangrove phyllosphere (Rigonato et al., 2012), yet two novel cyanobacteria genera were described inhabiting this ecosystem (Alvarenga et al. 2016).

The results obtained in this study provide the first genetic insight of cyanobacteria diversity in the Brazilian Atlantic forest plant species phyllospheres and contribute to the understanding of 
the hierarchy of ecological factors influencing the cyanobacterial colonization in this environment.

\section{Acknowledgements}

This study was supported by grants from the State of São Paulo Research Foundation (FAPESP/BIOTA 2008/50824-1). N. Gonçalves, J. Rigonato and A. P. D. Andreote were supported by FAPESP graduate fellowship (Grants 2009/12196-4, 2007/08354-5, 2009/15402-1, respectively). M. F. Fiore would also like to thank $\mathrm{CNPq}$ for a research fellowship (306607/2012-3).

\section{References}

Abril, A.B., Torres, P.A., and Bucher, E.H. 2005. The importance of phyllosphere microbial populations in nitrogen cycling in the Chaco semi-arid woodland. J. Trop. Ecol. 21: 103-107. Aguiar, R., Fiore, M.F., Franco, M.W., M.C. Ventrella, A.S. Lorenzi, Vanetti, C.A., Alfenas, A.C. 2008. A novel epiphytic cyanobacterial species from the genus Brasilonema causing damage to Eucalyptus leaves. J. Phycol. 44:1322-1334.

Alvarenga, D.O., Rigonato, J., Branco, L.H.Z., Melo, I.S. and Fiore, M.F. 2016. Phyllonema aviceniicola gen. et sp. nov. and Foliisarcina bertiogensis gen. et. sp. nov., novel epiphyllic cyanobacteria associated with Avicennia schaueriana leaves. Int. J. Syst. Evol. Microbiol. 66: $689-700$.

Baldoto, L.E.B. and Olivares, F.L. 2008. Phylloepiphytic interaction between bacteria and different plant species in a tropical agricultural system. Can. J. Microbiol. 54: 918-931.

Bentley, B.L. 1987. Nitrogen fixation by epiphylls in a tropical rainforest. Ann. Mo. Bot. Gard. 74: $234-241$. 
Blum, H., Beier, H. and Gross, H. 1987. Improved silver staining of plant proteins, RNA and DNA in polyacrilamyde gels. Electrophoresis 8: 93-99.

Branco, L.H.Z., Hoffmann, L., Teixeira, J.P., Ferreira, V., Morais-Filho, J.C. 2009. Aerophytic cyanoprokaryotes from Atlantic rainforest region of São Paulo State, Brazil: Chroococcales and Oscillatoriales. Cryptogamie Algol 30:135-152.

Büdel, B., Weber, H.M., Porembski, S., Barthlott, W. 2002. Cyanobacteria of inselbergs in the Atlantic Rain-forest zone of Eastern Brazil. Phycologia 41:498-506.

Clarke, K.R. and Gorley, R.N. 2006. Primer 6.0: user manual/tutorial. Plymouth: Primer-E, pp. 190.

Colombo, A.F. and Joly, C.A. 2010. Brazilian Atlantic Forest lato sensu: the most ancient Brazilian forest, and a biodiversity hotspot, is highly threatened by climate change. Braz. J. Biol. 70: $697-708$.

Dulla, G., Marco, M., Quiñones, B. and Lindow, S.E. 2005. A Closer Look at Pseudomonas syringae as a Leaf Colonist. ASM News 71: 469-475.

Finkel, O.M., Burch, A.Y., Lindow, S.E., Post, A.F. and Belkin, S. 2011. Geographical location determines the population structure in phyllosphere microbial communities of a salt-excreting desert tree. Appl. Environ. Microbiol. 77: 7647-7655.

Fiore, M.F., Sant'anna, C.L., Azevedo, M.T.P., Komárek, J., Kastovšký, J., Sulek, J., Lorenzi, A.S. 2007. The cyanobacterial genus Brasilonema, gen. nov., a molecular and phenotypic evaluation. J. Phycol. 43:789-798.

Freiberg, E. 1998. Microclimatic parameters influencing nitrogen fixation in the phyllosphere in a Costa rican premontane rain forest. Oecologia 17: 9-18.

Fritz-Sheridan, R.P. and Portécop, J. 1987. Nitrogen fixation on the tropical volcano, La Soufriere (Guadeloupe): a survey of nitrogen fixation by blue-green algal microepiphytes and lichen endophytes. Biotropica. 19: 194-199. 
Fürnkranz, M., Wanek, W., Richter, A., Abell, G. and Rasche, F. 2008. Nitrogen Fixation by phyllosphere bacteria associated with higher plants and their colonizing epiphytes of a tropical lowland rainforest of Costa Rica. ISME J. 2: 61-570.

Gama-Jr, W.A., Laughinghouse IV, H.D., Sant'Anna, C.L. 2014. How diverse are coccoid cyanobacteria? A case study of terrestrial habitats from the Atlantic Rainforest (São Paulo, Brazil). Phytotaxa 178:61-97.

Good, I.J. 1953. The population frequencies of species and the estimation of population parameters. Biometrika. 40: 237-264.

Hentschke, G.S., Johansen, J.R., Pietrasiak, N., Fiore, M.F., Rigonato, J., Sant'anna, C.L., Komárek, J. 2016. Phylogenetic placement of Dapisostemon gen. nov. and Streptostemon, two tropical heterocytous genera (Cyanobacteria). Phytotaxa 245(2): 129-143.

Joly, C.A., Assis, M.A., Bernacci, L.C., Tamashiro, J.Y., Campos, M.C.R., Gomes, J.A.M.A., Lacerda, M.S., Santos, F.A.M., Pedroni, F., Pereira, L.S., Padgurschi, M.C.G., Prata, E.M.B., Ramos, E., Torres, R.B., Rochelle, A., Martins F.R., Alves, L.F., Vieira, S.A., Martinelli, L.A., Camargo, P.B., Aidar M.P.M., Eisenlohr, P.V., Simões, E., Villani, J.P. and Belinello, R. 2012. Floristic and phytosociology in permanent plots of the Atlantic Rainforest along an altitudinal gradient in southeastern Brazil. Biota Neotrop. 12: 123-145.

Komárek, J., Sant’Anna, C.L., Bohunická, M., Mareš, J., Hentschke, G.S., Rigonato, J., Fiore, M.F. 2013. Phenotype diversity and phylogeny of selected Scytonema-species (Cyanoprokaryota) from SE Brazil. Fottea 13(2):173-200.

Lambais, M. R., Lucheta, A. R., and Crowley, D. E. (2014). Bacterial community assemblages associated with the phyllosphere, dermosphere, and rhizosphere of tree species of the Atlantic forest are host taxon dependent. Microb. Ecol. 68(3): 567-574. 
Lambais, M.R. and Crowley, D.E. 2014. Bacterial Diversity in Tree Canopies of the Atlantic Forest. Encyclopedia of Metagenomics. Springer Reference. Springer-Verlag. DOI 10.1007/SpringerReference_303983.

Lambais, M.R., Crowley, D.E., Cury, J.C., Bull, R.C. and Rodrigues, R.R. 2006. Bacterial Diversity in Tree Canopies of the Atlantic Forest. Science. 312: 1917.

Leitão Filho, H.F., Pagano, S.N., Cesar, O., Timoni, J.L. and Rueda J.J. 1993. Ecologia da Mata Atlântica em Cubatão. Paulista State University Ed/University of São Paulo, Campinas, Brazil, $184 \mathrm{pp}$.

Leveau, J.H. and Lindow, S.E. 2001. Appetite of an epiphyte: quantitative monitoring of bacterial sugar consumption in the phyllosphere. Proc. Natl. Acad. Sci. USAPNAS. 98:34463453.

Lindow, S.E. and Brandl, M.T. 2003. Microbiology of the phyllosphere. Appl. Environ. Microbiol. 69:1875-1883.

Mechaber, W.L., Marshall, D.B., Mechaber, R.A., Jobe, R.T. and Chew, F.S. 1996. Mapping leaf surface landscapes. Proc. Natl. Acad. Sci. USAPNAS. 93: 4600-4603.

Monier, J.M. and Lindow, S.E. 2003. Differential survival of solitary and aggregated bacterial cells promotes aggregate formation on leaf surfaces. Proc. Natl. Acad. Sci. USAPNAS. 100(26): $15977-15982$.

Neilan, B.A., Jacobs, D., Del dot, T., Blackall, L.L., Hawkins, P.R., Cox, P.T. and Goodman, A.E. 1997. rRNA sequences and evolutionary relationships among toxic and nontoxic cyanobacteria of the genus Microcystis. Int. J. Syst. Bacteriol. 47: 693-697.

Nübel, U., Garcia-Pichel, F. and Muyzer, G. 1997. PCR primers to amplify 16S rRNA genes from cyanobacteria. Appl. Environ. Microb. 63: 3227-3332.

Peñuelas, J., and Terradas, J. 2014. The foliar microbiome. Trends Plant Sci. 19(5): 278-280. 
Peñuelas, J., Rico, L., Ogaya, R., Jump, A. S. and Terradas, J. 2012. Summer season and longterm drought increase the richness of bacteria and fungi in the foliar phyllosphere of Quercus ilex in a mixed Mediterranean forest. Plant Biol. 14: 565-575. doi: 10.1111/j.14388677.2011.00532.x

Ribeiro, M. C., Martensen, A. C., Metzger, J. P., Tabarelli, M., Scarano, F. and Fortin, M. J. 2011. The Brazilian Atlantic Forest: a shrinking biodiversity hotspot. In Biodiversity Hotspots: Distribution and Protection of Conservation Priority Areas. Edited by F.E. Zachos, J.C. Habel, Springer, Berlin pp. 405-434.

Ribeiro, M. C., Metzger, J. P., Martensen, A. C., Ponzoni, F. J., and Hirota, M. M. 2009. The Brazilian Atlantic Forest: How much is left, and how is the remaining forest distributed? Implications for conservation. Biological Biol. ConservationConserv., 142(6): 1141-1153. Rigonato, J., Alvarenga, D.O., Andreote, F.D., Dias, A.C.F., Melo, I.S., Kent, A. and Fiore, M. F. 2012. Cyanobacterial diversity in the phyllosphere of a mangrove forest. FEMS Microbiol. Ecol. 80:312-322.

Rigonato, J., Kent, A. D., Alvarenga, D. O., Andreote, F. D., Beirigo, R. M., Vidal-Torrado, P. and Fiore, M. F. 2013. Drivers of cyanobacterial diversity and community composition in mangrove soils in south-east Brazil. Environ. Microbiol. 15: 1103-1114.

Saitou, N. and Nei, M. 1987. The neighbor-joining method: a new method for reconstructing phylogenetic trees. Mol. Biolog. Evol. 4: 406-425.

Sant'Anna, C.L., Azevedo, T.M.P., Kaštovskský, J., Komárek, J. 2010. Two form-genera of aerophytic heterocytous cyanobacteria from Brazilian rainy forest Mata Atlântica. Fottea 10:217228.

Sant’anna, C.L., Kaštovský, J., Hentschke, G.S., Komárek, J. 2013. Phenotypic studies on terrestrial stigonematacean Cyanobacteria from the Atlantic Rainforest, São Paulo State, Brazil. Phytotaxa 89:1-23. 
Scarano, F. R., and Ceotto, P. 2015. Brazilian Atlantic forest: impact, vulnerability, and adaptation to climate change. Biodivers. Conserv. 24(9): 2319-2331.

Schloss, P.D., Westcott, S.L., Ryabin, T., Hall, J.R., Hartmann, M., Hollister, E.B., Lesniewski, R.A., Oakley, B.B., Parks, D.H., Robinson, C.J., Sahl, J.W., Stres, B., Thallinger, G.G., Van Horn, D.J. and Weber, C.F. 2009. Introducing mothur: open-source, platform-independent, community-supported software for describing and comparing microbial communities. Appl.

Environ. Microbiol. 75: 7537-7541.

Tamura, K. Peterson, D. Peterson, N. Stecher, G. Nei, M. and Kumar, S. 2011. MEGA5:

Molecular Evolutionary Genetics Analysis using Maximum Likelihood, Evolutionary Distance, and Maximum Parsimony Methods. Mol. Biol. Evol. 28: 2731-2739.

Venkatachalam, S., Ranjan, K., Prasanna, R., Ramakrishnan, B., Thapa, S., and Kanchan, A.

2016. Diversity and functional traits of culturable microbiome members, including cyanobacteria in the rice phyllosphere. Plant Biol. doi:10.1111/plb.12441.

Yadav, R.K.P., Halley, J.M., Karamanoli, K., Constatinidou, H.I. and Vokou, D. 2004. Bacterial populations on the leaves of mediterranean plants: quantitative features and testing of distribution models. Environ. Exp. Bot. 52:63-77. 


\section{Tables}

Table 1 - Comparison of cyanobacterial communities from distinct plant species determined by ANOSIM statistical test (R).

\begin{tabular}{lll}
\hline Groups & Statistic R & Level of significance \\
\hline M. neesii x G. opposita & 0.651 & 0.002 \\
M. neesii x E. edulis & 0.513 & 0.004 \\
M. neesii x G. gardneriana & 0.781 & 0.029 \\
G. opposita x E. edulis & 0.264 & 0.011 \\
G. opposita x G. gardneriana & 0.679 & 0.002 \\
E. edulis x G. gardneriana & 0.540 & 0.004 \\
\hline
\end{tabular}


1 Table 2 - Taxonomic assignment of cyanobacterial sequences retrieved from phyllosphere of plants selected in PSP $_{\mathrm{E}}$ and PSP $\mathrm{N}_{\mathrm{N}}$ sites of Atlantic 2 forest. Number of $16 S$ rRNA gene clones belonging to each cyanobacteria genus (GenBank maximum identity); comparison of OTUs, richness 3 and diversity indices derived from $16 S r R N A$ gene clone libraries.

\begin{tabular}{|c|c|c|c|c|c|c|}
\hline & E. edulis PSP $_{\mathrm{E}}$ & G. gardneriana $\mathrm{PSP}_{\mathrm{E}}$ & G. opposita PSP $_{\mathrm{E}}$ & E. edulis $\mathrm{PSP}_{\mathrm{N}}$ & G. opposita PSP $_{\mathrm{N}}$ & M. neesii PSP $_{\mathrm{N}}$ \\
\hline \multicolumn{7}{|c|}{ - } \\
\hline Brasilonema & $10(96-97 \%)$ & $1(96 \%)$ & $n d$ & $1(95 \%)$ & $n d$ & $n d$ \\
\hline Dolichospermum-like & nd & $7(98 \%)$ & $1(95 \%)$ & nd & $n d$ & $n d$ \\
\hline Nostoc & $6(95-99 \%)$ & $38(95-99 \%)$ & $5(96-99 \%)$ & nd & $n d$ & $30(96-100 \%)$ \\
\hline Scytonema & nd & nd & $1(97 \%)$ & $n d$ & $2(96-97 \%)$ & nd \\
\hline Tolypothrix & $n d$ & $1(96 \%)$ & $n d$ & nd & $n d$ & nd \\
\hline Stigonemataceae & $3(93 \%)$ & $8(92-94 \%)$ & $1(94 \%)$ & $n d$ & $9(88-94 \%)$ & $n d$ \\
\hline Unidentified & $2(90-94 \%)$ & $1(94 \%)$ & $1(90 \%)$ & nd & nd & nd \\
\hline \multicolumn{7}{|l|}{ Oscillatoriales } \\
\hline Arthrospira-like & nd & $1(97 \%)$ & nd & $n d$ & nd & $4(97-99 \%)$ \\
\hline \multicolumn{7}{|l|}{ Pseudanabaenales } \\
\hline Wilmottia & nd & $n d$ & $n d$ & nd & $2(97 \%)$ & nd \\
\hline Leptolyngbya & nd & $2(96-98 \%)$ & $n d$ & $1(95 \%)$ & nd & $n d$ \\
\hline Unidentified & nd & $1(96 \%)$ & $1(93 \%)$ & nd & nd & nd \\
\hline \multicolumn{7}{|l|}{ Synechococcales } \\
\hline Synechococcus & $n d$ & $6(97-98 \%)$ & $8(99 \%)$ & $15(96-99 \%)$ & $12(98-99 \%)$ & $40(97-99 \%)$ \\
\hline Unidentified & $5(92-94 \%)$ & nd & nd & nd & nd & $5(92-94 \%)$ \\
\hline \multicolumn{7}{|l|}{ Chroococcales } \\
\hline Chroococcidiopsis & nd & $2(100 \%)$ & nd & nd & nd & nd \\
\hline Uncultured cyanobacterium & $55(89-97 \%)$ & $60(89-99 \%)$ & $68(86-98 \%)$ & $64(84-97 \%)$ & $62(87-99 \%)$ & $42(88-99 \%)$ \\
\hline Clone sequences & 81 & 128 & 86 & 81 & 87 & 121 \\
\hline Shannon & $3.02 \pm 0.08$ & $2.63 \pm 0.11$ & $3.09 \pm 0.11$ & $2.30 \pm 0.11$ & $2.86 \pm 0.10$ & $2.51 \pm 0.12$ \\
\hline ACE & $39.60 \pm 7.20$ & $57.70 \pm 16.40$ & $96.50 \pm 33.50$ & $34.00 \pm 11.00$ & $39.50 \pm 8.00$ & $72.20 \pm 23.10$ \\
\hline Chao 1 & $40.10 \pm 9.70$ & $66.50 \pm 29.70$ & $174.00 \pm 96.50$ & $32.50 \pm 12.50$ & $33.30 \pm 5.20$ & $121.30 \pm 76.70$ \\
\hline $\mathrm{ESC}$ & 0.874 & 0.887 & 0.744 & 0.895 & 0.885 & 0.844 \\
\hline
\end{tabular}

4 Numbers in parenthesis are the Genbank maximum identity values. $n d$ : not detected. OTU: operational taxonomic units, based on a 95\% similarity threshold; ACE and 5 Chao1: nonparametric richness estimators; Shannon: diversity index; ESC: estimated sample coverage. 


\section{Figure captions}

7 Fig. 1 - Clustering analysis determined by NMDS based on DGGE fingerprint comparing the

8 cyanobacterial community structure A) comparison based on different plant species B) comparison 9 based on different locations.

10

11 Fig. 2 - Phylogenetic tree of $16 S r R N A$ gene sequences of cyanobacterial clones obtained from the

12 phyllosphere of plants found in the Atlantic forest. Node values were determined by bootstrap analysis, 13 determined based on 1000 replications. Coloured figure in online version.

14

15 Fig. 3 - Absolute quantification, based on quantitative real time PCR of cyanobacterial $16 S r R N A$ gene 16 in the phyllosphere of targeted plant species. Values are represented as number of targeted gene per 17 leaf area, columns indicate the average log values from biological replications, and bars indicate the 18 standard error.*statistical differences evaluated by student t-test. 

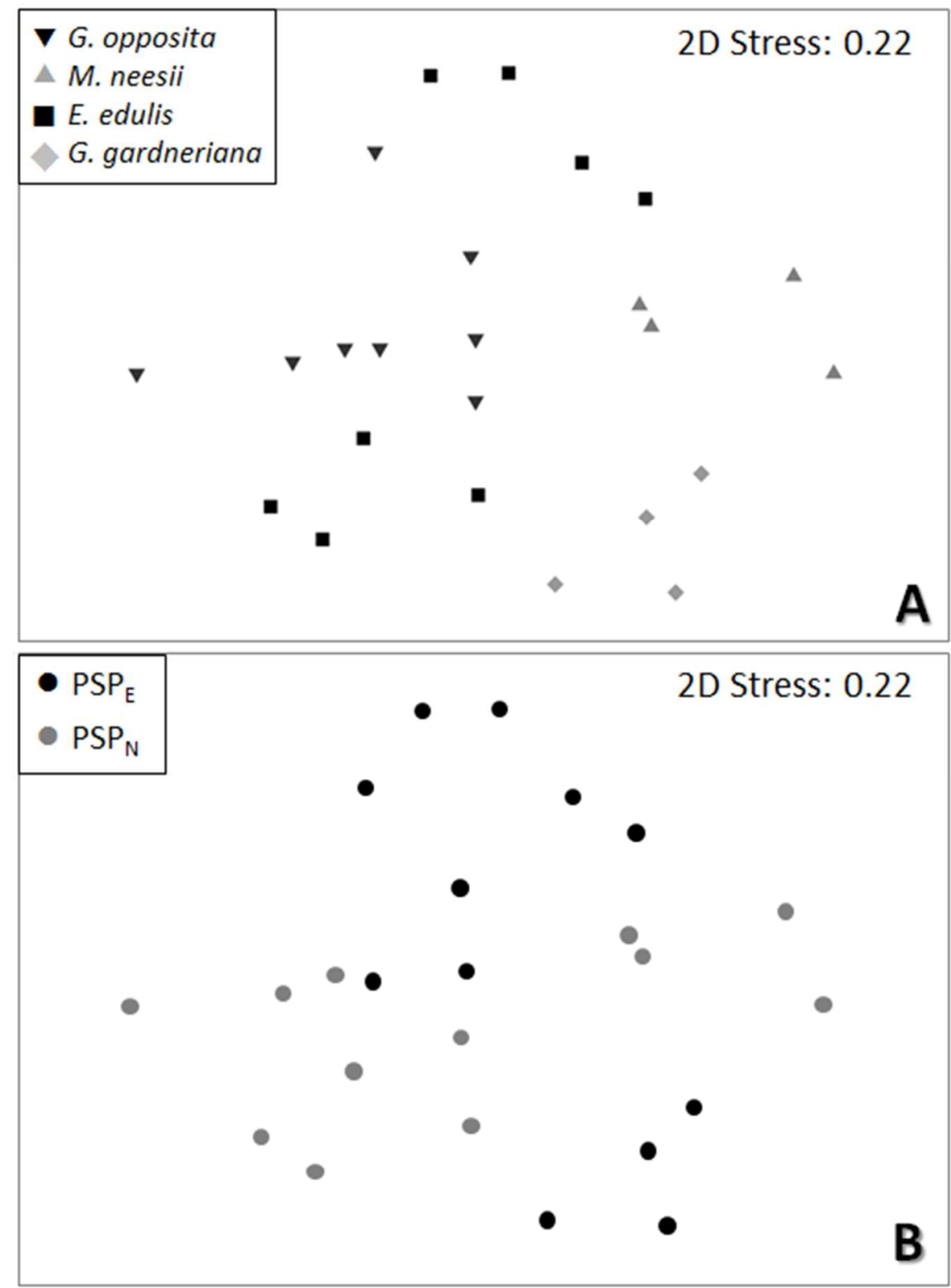

$99 \times 136 \mathrm{~mm}(300 \times 300 \mathrm{DPI})$ 


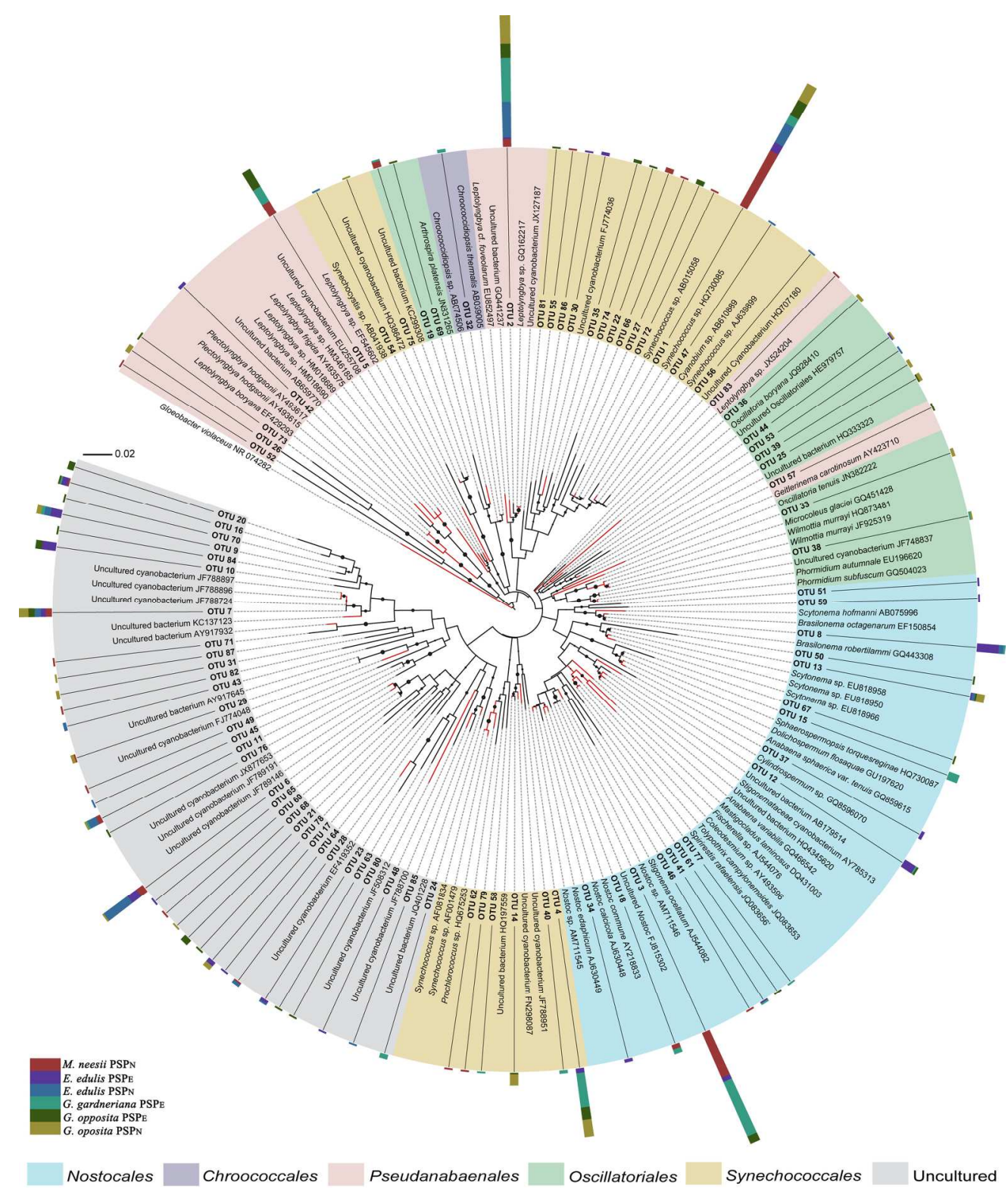

$742 \times 881 \mathrm{~mm}(72 \times 72$ DPI $)$ 


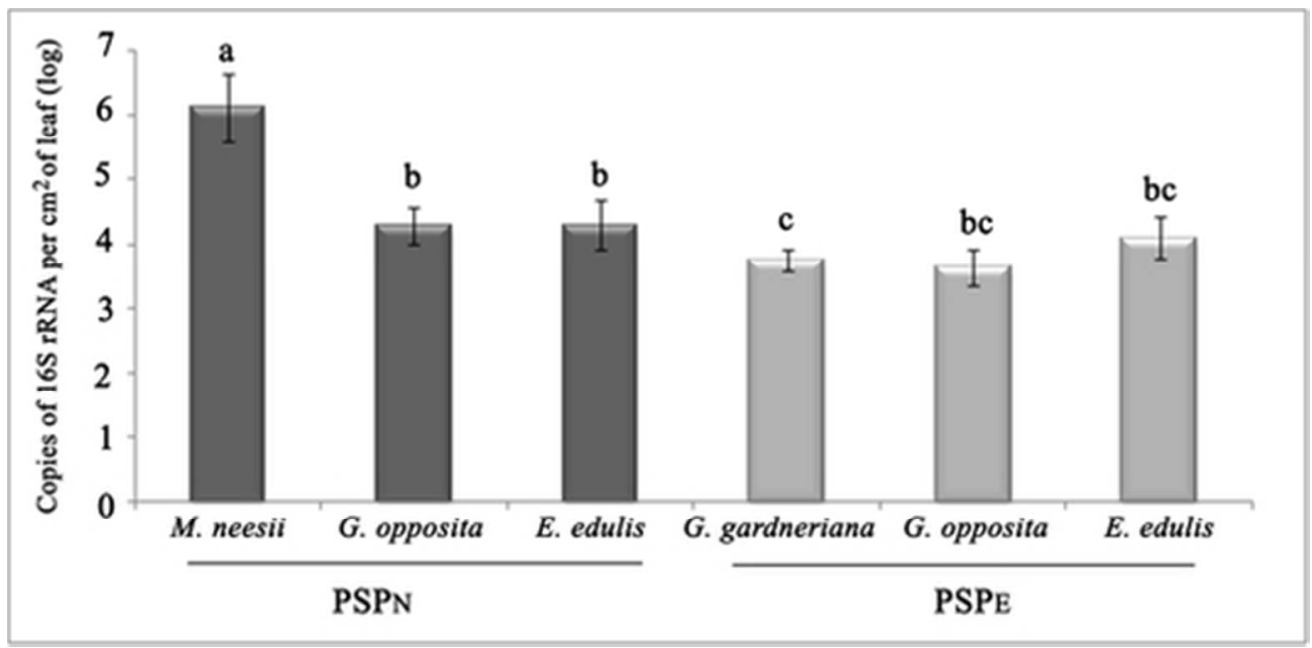

$187 \times 92 \mathrm{~mm}(72 \times 72 \mathrm{DPI})$ 